\title{
The Portrayal of Death and the Fear of Death in Julian Barnes' Nothing to be Frightened of
}

Julian Barnes' ın Korkulacak Bir Şey Yok Adlı Eserinde Ölüm ve Ölüm Korkusu

\author{
Gönül Bakay \\ Bahçeşehir University, Turkey
}

\begin{abstract}
Published in 2008, Nothing to be Frightened of deals with the universal fear of death from a variety of angles and perspectives. The book defies easy categorisation since it is a profoundly hybrid text which consists of a family memoir, meditations on death and the fear of death, as well as Julian Barnes' conversations with his brother who is a philosopher, there is also the reckoning of religion and of afterlife. The book also offers a powerful celebration of art and literature as attempts to achieve 'symbolic immortality'. Drawing on the insights offered by terror-management theory, this article aims to examine the humorous and witty treatment of death and the fear of death in Julian Barnes' Nothing to be Frightened Of. In the course of my analysis, I will particularly focus on the ways in which the writer engages with a number of alternative coping mechanisms people utilise while dealing with the fear of death. In doing that, I will also argue that Nothing to be Frightened of itself can be seen as Barnes' way of confronting his own mortality and tackling his own fear of death in order to relieve emotional tension engendered precisely by his own fear.
\end{abstract}

Keywords: Death, fear of death, terror-management theory, Julian Barnes, Nothing to be Frightened of

Öz

2008 yılında yayımlanan Korkulacak Bir Sey Yok evrensel bir korku olan ölüm korkusunu çeşitli perspektiflerden ve açllardan incelemektedir. Bu kitabı kategorize etmek kolay değildir zira aile anıları, ölüm ve ölüm korkusu üzerine tefekkür, Julian Barnes'ın bir felsefeci olan erkek kardeşiyle söyleşiler, din ve ölüm sonrası konuları üzerine incelemeleri kapsayan oldukça melez bir metindir. Kitap, aynı zamanda, "sembolik ölümsüzlüğe" ulaşma araçları da olabilen sanat ve edebiyatı yüceltir. $\mathrm{Bu}$ makale, korku yönetimi kuramının önermelerine atıf yaparak, Julian Barnes'ın Korkulacak Bir Şey Yok isimli eserinde ölüm ve ölüm korkusu konularının ele alınışını incelemektedir. Makale boyunca yazarın insanların ölüm korkusuyla baș etmeye çalışırken sıklıkla başvurdukları çeşitli savunma mekanizmalarına yaklaşımı üzerinde özellikle duracağım. Bunu yaparken aynı zamanda, Korkulacak Bir Şey Yok kitabını yazarken Julian Barnes'ın kendi ölümlülügüule nasıl yüzleştiğini ve yazım sürecinin ondaki ölüm korkusunun yol açtığı duygusal gerilimin yatıştırılması yönünde ona nasıl yardımcı olduğunu açıklayacağım.

Anahtar Kelimeler: Ölüm, ölüm korkusu, korku yönetimi kuramı, Julian Barnes, Korkulacak Bir Şey Yok 


\section{Introduction: Terror as an Adaptive Response to Death}

"People wait decades until something scares them into finally letting go, being present and loving fully, all the while not realizing that life itself is a near death experience." Cory Allen

"I don't believe in God but I miss him," remarks the celebrated British writer Julian Barnes. In his novels as well as short stories, Barnes frequently questions and examines how people feel about the inevitability of old age and death. His overall conclusion is that although people display different attitudes towards death, they generally fear it. Published in 2008, Nothing to be Frightened of deals with the universal fear of death from a variety of angles and perspectives. The book defies easy categorisation since it is a profoundly hybrid text including family memoir, meditations on death, conversations with his brother who is a philosopher, and the reckoning of religion and of afterlife. The book also offers a powerful celebration of art and literature as it attempts to achieve "symbolic immortality".

Early on in the book, Barnes talks with his mother about the concept of death and she says: "What's all this about death, by the way?" Barnes responds by saying that he doesn't like it. His mother then says: "You're just like your father" adding: "Maybe it's your age. When you get to my age, you won't mind so much. I've seen the best of life anyway" (7). This exchange clearly shows how the appraisal of death and consequently how one feels vis-à-vis death is a deeply subjective phenomenon. Unlike her mother, who seems to have cultivated a sense of acceptance in the face of impending death, Barnes appears to be strongly upset and profoundly concerned with death. It is possible to suggest that the writer's lack of religious faith has had a strong bearing on his strong and constant preoccupation with death throughout his life. Regarding the subject of religion and faith, Barnes states:

Faith is about believing precisely what, according to all the known rules could not have happened. The virgin birth, the Resurrection, Muhammad leaping out to heaven leaving a footprint in the rock, life hereafter. It couldn't have happened by all we understand. But it did. Or, it will. (Or, of course, it certainly didn't and assuredly won't) (78)

Although the subject of religious faith, and lack thereof, figures predominantly throughout the book, Barnes depicts the subject of death from a variety of different perspectives and tries to express "the complex relation between memory, emotion, postmodernism and Englishness" in his exploration of death (Callus 55). Drawing on the insights offered by terror management theory, this paper aims to examine the humorous and witty treatment of death and old age in Julian Barnes' Nothing to be Frightened Of. In the course of my analysis, I will particularly focus on ways in which the writer engages with a number of alternative coping mechanisms people utilise while dealing with the fear of death. In doing that, I will also argue that Nothing to be Frightened of itself can be seen as Julian Barnes' way of confronting his own mortality and tackling his 
own fear of death in order to relieve the emotional tension and pain engendered by his fear.

According to Solomon et al. the ever-present potential for incapacitating terror caused by death is the "worm at the core" of the human condition (24). In their words: "Terror is the natural and generally adaptive response to the imminent threat of death" (23). In accordance with that, the really tragic part of our condition is that "only we humans, due to our enlarged and sophisticated neocortex, can experience this terror in the absence of looming danger [...] This realization threatens to put us in a persistent state of existential fear" (24). As a writer, Barnes is acutely aware of this particular form of "existential fear" and tries to deal with and dispel it through the act of writing. The book as a whole offers a very interesting and admittedly humorous thought experiment on a subject that the majority of people would regard as very serious and bleak. Moreover, it also has a remarkably conversational tone that invites the reader to engage with the material presented on a personal level. Early on in the book, Barnes says: "some of this book will strike you as amateur, do it yourself stuff... yet we are all amateurs in our own lives" (38). As this quote illustrates, the writer's authorial voice is quite impersonal and the writer addresses the reader almost as a friend he is sharing his observations and memories with.

\section{Fear of Death and Subjective Response}

In the course of their evolutionary history, human beings have often turned to religion and varieties of spirituality to deal with their deep-rooted fear of death. Terrified by the prospect of their imminent extinction, they have sought solace in the possibility of an afterlife. Fully aware of the ramifications of belief and faith in relation to the subject of death, Barnes questions the 'true' meaning of being religious and that of being a non-believer throughout his book. In an interview, Barnes observes: "I fear death and I believe there is nothing after it, but does this necessarily make it courageous of me not to believe in God? I just think he doesn't exist and that's it" (Guignery and Roberts 2009). He remarks that even amongst his close family members there were differences of opinion regarding the meaning attributed to the concept of religion.

Within this context, Barnes talks a lot about his brother Jonathan with whom he had intellectual disagreements on several subjects. When asked how wise the philosophers were in their own lives, his brother bluntly answers: "not a bit wiser for being philosophers" (126). Julian Barnes' brother also entertains very different views regarding the fear of death when compared with Julian. According to Julian Barnes:

You come into the world, look around, make certain deductions, free yourself from the old bullshit, learn, think, observe, conclude. You believe in your own powers and autonomy; you become your own achievement. So, over the decades, my fear of death has become an essential part of me, and I would attribute it to the exercise of imagination; while my brother's detachment in death's face is an 
essential part of him which he probably ascribes to the exercise of logical thought. (63)

Here, Barnes emphasizes the agency of the individual as the creator of his own selfhood in interaction with his environment. As he asserts, the individual is never fixed or static, he is rather an unfolding event always in the making, and never complete. Barnes also implies that we are complex creatures made by the world we inhabit as well as by our own thoughts. In this sense, Barnes' powerful imagination fosters a fear of death, whereas his more logical brother is more detached about the subject. His brother's stoic detachment in the face of the inevitability of death is something alien to Barnes, who has integrated the fear of death into his character. Barnes further observes: "My brother and I are now both over sixty, and I have just asked him a few pages ago - what he thinks of death" (62). When his brother replies: "I am quite content with the things as they are," Barnes wonders whether it is his brother's immersion in philosophy that has reconciled him to the brevity of life. (62). For his own part, his brother attests that he has simply made his peace with the certainty of an event beyond his control: "I know it's going to happen and there is nothing I can do about it," he says, adding that possibly at the best he may have fifteen years of life ahead of him (62). Unlike his brother, Julian Barnes can imagine various alternatives that would have been more welcome: "how about being given the option to die when you felt like it, when you've had enough: to go on for two or three hundred years and then be allowed to utter you own euthanasiastic: oh get on with it, then' at a time of your own choosing" (63). Although entertaining such thoughts could certainly be seen an exercise in futility, one cannot help but admire-and perhaps empathise with-Barnes' witty take on such an admittedly bleak subject. Reading between the lines, we might also be tempted to think that Barnes could also be rebelling against the helplessness of the individual who has no choice when it comes to the finality of his own life. We have not made the choice to be born, neither do we have any choice about death.

\section{Coping Mechanisms: Religion, Science and Art}

In the light of these preliminary observations, it is possible to suggest that human beings' constant preoccupation with death has engendered an existential crisis with far-fetching implications. Julian Barnes himself is a good example of the intelligent and deep-thinking individual who is tormented by his reflective capacity. Humans are endowed with a highly sophisticated prefrontal cortex that allows them to project themselves into the past as well as into the future. However, our heightened cognitive capacity is both a blessing and a curse: while it is thanks to our intelligence that we were able create civilisations, the same intelligence also breeds anxiety and terror in the face of the looming presence of death. As Solomon et al. maintain:

Once our intelligence had evolved to the point that this ultimate existential crisis dawned on us, we used that same intelligence to devise the means to keep that potentially devastating existential terror at bay. Our shared cultural worldviews-the beliefs we create to 
explain the nature of reality to ourselves-give us a sense of meaning, an account for the origin of the universe, a blueprint for valued conduct on earth, and the promise of immortality. (25)

Hence, "cultural worldviews" have historically served a very important function in the management of terror caused by death. As Solomon et al. further suggest, of primary importance amongst these cultural worldviews are the grand narratives offered by world religions: "cultural worldviews have offered immense comfort to death-fearing humans. Throughout the ages and around the globe, the vast majority of people, past and present, have been led by their religions to believe that their existence literally continues in some form beyond the point of physical death" (25).

Similarly, Barnes acknowledges that people are strongly motivated to turn to a higher transcendental source and the concept of an afterlife to deal with the fear and reality of death. While Barnes accepts that belief in God and eternity can certainly ease the fear of death, he cannot find any consolation for himself in religion or God since he is an agnostic. He thinks that we might consider several options: “God exists, God doesn't exist, God exists but has abandoned us. God used to exist, but does not exist at the moment, he has taken a divine sabbatical. One thing we may have overlooked is maybe God is an ironist and making fun of us" (21). This idea of a "trickster" God is a far cry from the Christian perception of God as a benevolent father figure watching over us. The idea of a God who "sports" with life reminds us of the anthropomorphic Gods and Goddesses of mythology who embody human traits and show human weaknesses. The absence of a benevolent, compassionate Almighty and the possibility that God uses as some entertainment tool is even more disturbing than an absent God.

In brief, Barnes himself is deprived of the consolations of faith in God and religion in dealing with death. Instead, his outlook is fundamentally based on his own learning and the findings of modern science:

Life is a matter of random chance, man and his/her psychic life are products of evolution and there is no reason to believe that with Homo sapiens the process of evolution has come to an end: in the future human beings might well be replaced by other species more adaptable to the environment. Human altruism is an example of adaptive mechanisms, like, incidentally human fear of death. Death itself in turn is pre-programmed in living organisms, whose basic function is not prolonged human existence but transmission of genes. (Teske 2)

This is a very cut and dry, unsentimental perspective on human existence. It is also very mechanical and leaves no room for a higher order of "meaning" that might provide a consolation for the brevity of life. A man may fear his death but what is he? A mass of neurons. We do not produce thoughts, thoughts produce us. The brain is a lump of meat and the soul is merely "a story the brain tells itself". This materialist perspective provides a very bleak view regarding the 
prospects of the human subject whose existence is reduced to its biophysiological activities. So, ultimately, there is no comfort for Barnes in science.

Julian Barnes remarks that "Fear of death replaces fear of God. But fear of God at least allowed for negotiation.... We can't do the same with death. Death can't be talked down, or parleyed into anything: it simply declines to come to the negotiation table" (69). As this quote aptly illustrates, the reader constantly feels the anxiety of the author who doesn't believe in God or in after life but dreads his own mortality. Had Barnes been a believer, his dread probably wouldn't have been so strong. Yet in the absence of any sustaining illusions, he can hold on to, Barnes repeatedly maintains that the human being is completely left to his own devices when dealing with death. The apparent powerlessness of the individual vis-à-vis death is terrifying but also profoundly humbling.

Barnes states that his lack of religiosity is partly a result of his upbringing. He reveals that he belonged to a liberal family; his mother was an atheist and his father was an agnostic. In his words: "I was never baptized, never sent to Sunday School, I have never been to a normal church service in my life... I am constantly going into churches, but for architectural reasons; and more widely to get a sense of what Englishness once was" (Barnes 2008: 25). For Barnes Christianity is a cultural narrative that has had universal appeal because its message has resonated with certain deep-rooted needs in people and it was a well-written and engaging narrative: "It lasted because it was a beautiful lie, because the characters, the plot, the various coups de theatre the overreaching struggle between Good and Evil made up a great novel" (53). Hence, it has been the powerful appeal of a well-constructed narrative that spoke to mortal humans who perpetually suffered due to existential anguish. As an explanatory "Grand Narrative," Christianity not only spoke to people's neverending anxieties and fears but also offered them the hope of salvation. It is thus the emotional appeal of the doctrine that has had a powerful grip over the hearts and minds of people that made them believe what Barnes considers a beautiful, well-constructed lie.

In this context, the turn to and dependence on religion has been intimately linked with man's eternal quest for meaning in a seemingly absurd universe. However, Barnes believes that meaning of life resides where religion is drained. Thus, Barnes tries to find a meaning in Art, in the God of Art. For him, turning to art, instead of religion, for meaning is more appealing. Our contemporary period is also experienced as the era of "post-religion" in many parts of Europe, including England. In an interview on the decline of religious faith, Barnes says: "When a great story ends ... we all miss it ... There were aspects of it that leave a sense of want" (qtd. in Deflory 5).

Solomon et al. make a similar point with their distinction between "literal immortality" that is promised by many religions and "symbolic immortality" that is immortality through socio-cultural constructs: 
Our cultures also offer hope of symbolic immortality, the sense that we are part of something greater than ourselves that will continue long after we die. This is why we strive to be part of meaningful groups and have a lasting impact on the world-whether through our creative works of art or science, through the buildings and people named after us, through the possessions and genes we pass on to our children, or through the memories others hold of us. (26)

Although forms of "symbolic immortality" have always had a powerful grip over the human psyche, their appeal has certainly intensified and found a wider following with the decreasing role of official religion, especially in the advanced capitalist countries of the west. As Solomon et. al. further suggest: "These cultural modes of transcending death allow us to feel that we are significant contributors to a permanent world. They protect us from the notion that we are merely purposeless animals that no longer exist upon death. Our beliefs in literal and symbolic immortality help us manage the potential for terror that comes from knowing that our physical death is inevitable" (26).

In this sense, Barnes himself dwells at some length on the subject of immortality through art-that is "symbolic immortality-which is a theme explored by many artists throughout history. Barnes too believes that through the act of writing, he can make his own death a bit more difficult, he can perhaps "postpone" it: people may remember him when he is gone through his works but one day, there may be one last reader that will put him completely in oblivion. So as long as his books continue to "exist," Barnes will also exist in some shape or form, at least in the minds and memories of his readers. It is only when the writer ceases to exist as a thought also that he will finally be "dead". This kind of "death" could perhaps be more appropriately called "extinction" because it carries a stronger sense of finality.

As these reflections suggest, there is a very close relationship between memory, identity and existence. As Kermode contends: "the imagination ... is a form-giving power in relation to the creation of stories" (Deflory 8). During his introspection of his own life, Barnes - like any other person - also reconstructs and reinterprets certain events from his past. What we remember as well as how we remember it has significant bearing on our identity. Our identity, our perception of who we are, gives a shape to our memories. In the book, this is evident in the discussions on their grandparents where Barnes and his brother disagree on several points. Barnes, believing that his grandfather had favoured his brother, observes that when his grandfather died, he left him nothing whereas his brother disagrees saying: "he left you his gold watch". This little anecdote goes on to prove that we perceive everything, including past events, through our subjective mental filters. No matter how hard we try, our memories-just like our perceptions-are flawed and skewed. We cannot help but be biased observes of everything including the past. 


\section{Creative Transcendence}

A good question that might arise is the following: Why does Barnes fear death since he does not believe in life after death? Can one fear nothingness? Thanatophobia - fear of death-certainly appears to be a fact in Barnes' lifethe writer obsessively thinks about death all the time. He awakens from sleep bathed in sweat and sometimes shouts. He imagines himself on an overturned ferry, or locked in a car and driven into a river or being taken underwater in the jaws of a crocodile. In this regard, Barnes' vibrant imagination becomes a curse. It is because of his powerful imaginative faculty that he suffers the pain of a million deaths created in his mind's eye. So, it is not only the reality but also the contemplation of death that might figuratively 'kill' a person many times before the event of his physical (actual) death.

The obvious irony is that one cannot be truly alive and appreciate life if he does not confront the fact of death. Carpe Diem (seize the day) cannot be realized without Memento Mori (remember death). As Barnes maintains: "For me, death, is the one appalling fact which defines life; unless you are constantly aware of it, you cannot begin to understand what life is about; unless you know and feel that the days of wine and roses are limited, and the roses turn brown in their stinking water before all are thrown out forever-including the jugthere is no jug-there is no context to such pleasures and interests as come your way on the road to the grave" (126). As Barnes aptly suggests, how can one truly know and appreciate the value of something without contemplating its absence? What would be the value of life if we were immortals? It is, in other words, the inevitable finality of life and our recognition of this fact that helps us know the worth of life and the living. When we remind ourselves that nothing lives for ever, we learn to appreciate existence as long as it lasts.

In his well-known work on literary criticism, The Sense of an Ending: Studies in the Theory of Fiction, Frank Kermode argues that the main reason why people create stories is the desire to give order to the chaotic design of the world. They try to bring order to chaos by writing stories with beginnings, middles and ends. The past always influences the present. Barnes' desire to reconstruct a single true account of the past can be observed in his exploration of our understanding of, and relationship with, the historical past in such works as Flaubert's Parrot, Staring at the Sun, A History of the World in 10 and 1/2 Chapters and Arthur and George among others (Deflory 2). However, in his more recent works, Barnes has dealt with the more personal aspects of the past. Barnes had dealt with the topic of death in his earlier fiction such as Metroland and Lemon Table. However, in his more recent works, he writes about bereavement and sorrow from a more personal space. Undoubtedly, the fact that he lost his wife in 2008 may have had a serious effect on his decision to focus on these subjects. The Sense of an Ending, Pulse, and Levels of Life are some examples of this shift.

In this context, the death of his parents looms large in Barnes' book. The writer maintains that people don't usually die from the cause that they imagine they will die from. Doctors thought that his father would die of a stroke, heart 
trouble or abscesses of the lung, whereas Barnes thinks he died of giving up hope and exhaustion. His father is portrayed as a man who was resigned to situations he could not change. His mother, on the other hand, seems to have been the bossy type. Barnes believes that his father feared death whereas his mother feared incapacity and dependence more. His mother said she was glad that Julian hadn't seen his father during his last days as he was very shrunken, stopped eating and drinking and didn't speak. However, on her final visit, when she asked him if he knew who she was, he answered with the following words, which were probably his last: "I think you are my wife" (162).

Barnes always thought that his father's death would be the hardest death, since he loved him more but it turned out to be just the opposite. His father's death was his death whereas his mother's death was their death: it was the crumbling down of the family home... Things to be given away, letters, photographs to be torn up or put aside, etc. Barnes looks at his mother's body for a long time after her death. He observes: "Well done, Ma" and further states: "she had indeed done dying "better" than my father. He had endured a series of strokes, his decline stretching over years; she had gone from first attack to death more efficiently and speedily" (11).

Barnes is a great admirer of the philosopher Jules Renard. In fact, his own philosophy and his own views on life and death reflect Renard's philosophy to a large extent. Barnes is constantly preoccupied with the notion of death and when his friend $\mathrm{R}$ asks how often he thinks of death Barnes answers at least once a day (23). Yet he adds that he has got friends in much worse condition than he is in. For instance, one friend's death fright started at the age of four and continued well into his maturity, getting worse and worse. In his adult years, this friend turned out to be in a much worse state than Julian, thinking about death all the time. Barnes suggests that maybe thinking about death all the time is a good idea since it may be better to familiarize oneself with the reality of mortality.

As Solomon et.al. suggest: "Creative transcendence is obtained by contributing to future generations through innovations and teaching in art, science, and technology" (69). Barnes also entertains the possibility of "creative transcendence" and that his fear of death may therefore be connected with his chosen vocation of writing. He remembers the case of a comedian who was urged by a psychotherapist to question why he had become a comedian. When the comedian found out the reason, he stopped being a comedian. Thus, Barnes does not want to think in depth about the reason why he eventually became a writer. He thinks maybe the psychologists after examining him might say:

Mr. Barnes, we have examined your condition and we conclude that your fear of death is intimately connected to your literary habits which are, as for many in your profession, merely a trivial response to mortality. You make up stories so that your name and some indefinable percentage of your individuality, will continue after your physical death, and the anticipation of this brings you some kind of consolation. And although you have intellectually grasped that you might well be 
forgotten before you die, or if not, shortly afterwards, and that all writers will eventually be forgotten, as will the entire human race, even so it seems to you worth doing. (67)

These psychologists might also suggest that they have developed a new brain operation that takes away the fear of death and then add that it is a straightforward procedure which doesn't require a general anaestheticindeed you can watch its progress on the screen. The operation will of course take away the writer's desire to write but they continue saying. "Many of your colleagues have opted for this operation but found it most beneficial. Nor has society complained about there being fewer writers" (67). In his customary witty tone, Barnes thinks that maybe he can negotiate for a better deal: "How about eliminating not the fear of death but death itself? You get rid of death and I'll give up writing" (67).

Barnes writes not only about his fear of death but about his fear of dying while he is writing a book, without having the chance to complete it. He even suggests to the reader that the reader can die before he finishes reading the book. Barnes thinks that for the writer also there are two options: "Would you rather die in the middle of a book and have some bastard finish it for you or leave behind a work in progress that not a single bastard in the whole world was remotely interested in finishing?" (109).

As I have suggested throughout, there is a felt resistance to death as not only evident in the title but it is also felt in various discourses on death throughout Nothing to be Frightened Of. In an interview on the subject of this book, Barnes remarks:

You mustn't turn death into a metaphor, a guy with a scythe, Death isn't a single stalking figure that cuts you down. Death is just a process. It's just like some terrible, heartless, bland bureaucracy at work, busily fulfilling its quota, as it always does. To personify death with too many grades of emotion is to do it too much honour. (Gholami 123)

As Gholami observes, Barnes tries to resist death through several means in his book. He tries to resist death through bodily experiences, through the narrative and through the discourse of literature.

On the other hand, "Englishness" is a topic that Barnes frequently elaborates on in most of his novels including England, England. In Nothing to be Frightened of, Barnes deals with the emotion of fear and dread in the face of death in a peculiarly English way. As Callus observes:

And yet this emotion, dread, is throughout conveyed with wry elegance. It is an exquisitely controlled and faultlessly judged performance and contradictorily self-effacing, self-baring emotion: a quite English staging of wistfulness where the balance between surgical reminiscence and deprecating self-knowledge is abated by the suave irony that drives the narration, and which saves the text from being oppressive. (62) 
Barnes himself drew attention to how he employs humour and wit "to deflate the pathos by introducing something comic that is a very strong strand of British literature from Shakespeare onwards" (Callus 62). It could be suggested that Barnes once again displays a typical characteristic of the English, by being restrained when expressing "emotions" in this book. The dread Barnes feels in the face of "death" is a private emotion and typically, Barnes deals with this emotion "discreetly". The method Barnes uses in this book specifically is "humour".

For Barnes, irony is an important tool when dealing with the gloomy subject of death. Barnes believes that death is a culmination of the process that begins with the moment of our birth. He also states that in Montaigne's time, for instance, living up to old age was something rare, whereas, in our day and age, we tend to assume that living a long life is our right (40). In the words of OréPiqueraes: "For Barnes, having death present and actually talking about it is a way of learning both about life and death, since he himself quotes from Flaubert: "Everything must be learned from reading to dying" (95). From this perspective, meditating one one's mortality can be perceived as a form of philosophical practice that brings wisdom. We cannot really understand life in general and our own lives in particular without pondering on our finitude. Hard as it may seem, coming to terms with human mortality is part of our personal growth and development.

\section{Conclusion}

Julian Barnes' Nothing to be Afraid of provides a memorable illustration of many insights provided by terror management theory which argues that: "the combination of a basic biological inclination toward self-preservation with sophisticated cognitive capacities renders us humans aware of our perpetual vulnerabilities and inevitable mortality, which gives rise to potentially paralyzing terror" (215). As he reveals at many points throughout his book, Barnes himself suffers from this "potentially paralyzing terror" and he also argues that it is a universally experienced phenomenon. Like Solomon et. al., Barnes is also keenly aware of the various coping mechanisms people have utilised in order to deal with the terror stemming from the fear of death:

Cultural worldviews and self-esteem help manage this terror by convincing us that we are special beings with souls and identities that will persist, literally and/or symbolically, long past our own physical death. We are thus pervasively preoccupied with maintaining confidence in our cultural scheme of things and satisfying the standards of value associated with it. (Solomon et al. 216)

As Barnes points out, an important subject that cannot be separated from the concept of death is the concept of life, especially with regards to the fact that when one dies, one will inevitably lose connection with the many blessings of life experience. In this sense, contemplating our mortality may become a means of appreciating the beauty of life. Barnes observes that we do not have to believe in God in order to marvel at the beauties around us: "the harmony of 
the snow flake, and the complex allusiveness of the passion flower to the spectacular showmanship of a solar eclipse. If everything still moves without a Prime Mover, why should it be less wonderful and less beautiful?" (71).

Barnes maintains that there is one good news and one bad news. Better listen to the good news first, maybe you can die before you hear the bad news. The good news is that we indeed get wiser as we grow older. The bad news, on the other hand, is: for every decade of life after the age of fifty the brain loses two percent of its weight. Barnes remembers the well-known saying that "We have been given the miracle of life because trillions and trillions of living things have prepared the way for us and then have died- in a sense for us" (179). However, Barnes rejects this belief saying: "There is no logical reason why the continuity of our species should depend on my death, or yours, or anybody else's. The planet may be getting a bit foolish, but the universe is empty - Lots Available -, as the cemetery placard reminds us" (176).

In brief, Nothing to be Frightened Of entails Julian Barnes' meditations on death, the death of his loved ones as well as other writers he admires. Despite his considerable and apparently lifelong efforts to understand death, he has not been able to reach a concrete idea about what life and death are all about. Like the celebrated philosopher Renard, Barnes observes: "One does not grow old. Where the heart is concerned, the fact is accepted, at least in matters of love. Well, it is the same with the mind. It always remains young. You do not understand life any more at forty than you did at twenty, but you are aware of this fact, and you admit it. To admit it, is to remain young" (12).

The concept and reality of death has engaged the minds of greatest thinkers and ordinary people alike since the beginning of time. Julian Barnes brings his own unique attitude to this subject in this remarkable book. However, like many others who dealt with this subject, he has no clear solutions nor explanations to offer. What he basically does is to approach the concept of death from various angles and perspectives, fusing personal anecdotes and memories in his usual witty style. Barnes believes that to die is to be "nothing". How can one be frightened of "nothing"? So, he concludes: "There is Nothing to be Frightened of".

\section{Works Cited}

Barnes, Julian. Nothing to be Frightened Of. Alfred A Knopf, 2008.

Callus, Ivan. "There is great unrest: Some Reflections on Emotion ad Memory in Julian Barnes' Nothing to be frightened Of and The Sense of an Ending." Prague Journal of English Studies, 1.1, 2012, pp. 55-64.

Gholami, Soudabe. "Resistance to the Discourse of Death in Nothing to be Frightened of by Julian Barnes in the light of Michael Foucault." CS Canada, Studies in Literature and Language, Vol. 3, No. 2, 2011, pp. 123-128.

Guignery, Vanessa and Roberts, Ryan (eds). "Interview with Julian Barnes." Conversations with Julian Barnes. University Press of Mississippi, 2009. 
Kermode, Frank. The Sense of An Ending: Studies in the Theory of Fiction with a New Epilogue. Oxford University Press, 2000.

Lopez-Deflory, Estefania. "Beginnings, Middles, and Ends: A Kermodian Reading of Julian Barnes's Nothing to be Frightened Of and The Sense of an Ending." English: Journal of English Association, Vol. 65, Summer 2016, pp. 158-173.

Oré-Piqueras, Maricel. "Exploring the Path to Death Through Barnes's Older Characters: Between Irony and Melancholic Meditation.” Aging Studies, 44.15, 2017, pp. 15-21.

Renard, Jules, The Journal of Jules Renard (translated and edited by Louise Bogan, Elisabeth Roget). George Braziller, 1964.

Solomon, Sheldon, Jeff Greenberg and Tom Pyszczynski. The Worm at the Core: On the Role of Death in Life. Random House, 2015.

Teske, Joanna Klara. "Nothing to be Frightened Of": Julian Barnes' Meditation on Death." (Non)omnis moriar: Cultural and Literary Discourses of Death and Immortality. UMCS, 2012. pp. 225-232. 